International Journal of Current Advanced Research

ISSN: O: 2319-6475, ISSN: P: 2319 - 6505, Impact Factor: SJIF: 5.995

Available Online at www.journalijcar.org

Volume 6; Issue 3; March 2017; Page No. 2980-2986

DOI: http://dx.doi.org/10.24327/ijcar.2017.2986.0160

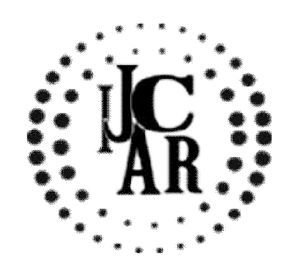

Research Article

\title{
EFFECTIVENESS OF COMMUNICATION BOARD ON COMMUNICATION AND LEVEL OF FRUSTRATION AMONG MECHANICALLY VENTILATED POST CARDIOTHORACIC SURGERY PATIENTS
}

\author{
Pramila Gaudel and Jamuna Bai
}

Narayana Hrudayalaya College of Nursing, RGUHS, Bangalore, India

A R T I C L E I N F O

\section{Article History:}

Received $20^{\text {th }}$ December, 2016

Received in revised form $19^{\text {th }}$ January, 2017

Accepted $4^{\text {th }}$ February, 2017

Published online $28^{\text {th }}$ March, 2017

\section{Key words:}

Mechanically ventilated,

communication board, frustration.

\begin{abstract}
A B S T R A C T
Mechanically ventilated patients experience many barriers while communicating their needs. It is important to develop alternative methods of communicating for those patients. The objectives of the present study were: to assess the communication and level of frustration among the selected patients, to assess the effectiveness of communication board on communication and level of frustration, to find correlation between communication and level of frustration, to find association between communication and level of frustration among patients. A quantitative research approach, true experimental design with a post test only control group design was adopted. A total sample size of 60 was selected by random sampling. Findings of the study showed that the communication board was effective in improving communication $(\mathrm{t}=9.051, \mathrm{p}=0.001)$ and frustration $(\mathrm{t}=-6.604, \mathrm{p}=0.001)$ of mechanically ventilated post cardio thoracic surgery patients. There was a statistical significant strong negative correlation $(r=-.543)$ between the communication and level of frustration. And there was no significant association between communication and level of frustration $(\mathrm{p}=0.05)$ with their selected baseline variables in both the experimental and control group. To conclude, communication board helped to improve communication and erase frustration of mechanically ventilated patients to some extent.
\end{abstract}

Copyright $(2017$ Pramila Gaudel and Jamuna Bai. This is an open access article distributed under the Creative Commons Attribution License, which permits unrestricted use, distribution, and reproduction in any medium, provided the original work is properly cited.

\section{INTRODUCTION}

Nursing is a communicative intervention that must strive for mutual understanding, co-ordination and co-action [1]. Interacting with those who have conditions that impaired communication requires special thoughts and sensitivity. Such patients benefit greatly when the nurses adapt communication techniques to suit their unique circumstances. By the year 2005, the total number of cardiovascular disease deaths had increased globally to 17.5 million from 14.4 million in 1990[7]. About 60,000 coronary bypass surgeries are done annually in India [4]. Caring for patient in mechanical ventilator is the integral part of nursing care in critical care unit. Positive patient outcomes depend on an understanding of the patient care needs as well as communication with the patient and among member of the health care team [9]. To communicate more effectively, the nurse should employ a variety of methods [5]. The use of different types of boards such as magic slate board, magnetic plastic letters and board, a picture board and a sample writing board could be used as intervention to enhance communication of patient during mechanical ventilation. By using the different types of communication boards health care practitioners can easily identify the problems [2].

\section{Objectives of the study}

1. To assess the communication and level of frustration among the experimental and control group by using Likert scale.

2. To assess the effectiveness of communication board on communication and level of frustration by using Likert scale.

3. To find correlation between communication and level of frustration among the experimental and control group.

4. To find association of communication and level of frustration in experimental and control group with their selected baseline variables.

\section{Hypothesis of the study}

\section{All hypothesis was tested at 0.05 level of significance}

- $\mathbf{H}_{\mathbf{1}}$ - There is a significant difference in the communication and level of frustration between the experimental and control group.

- $\mathbf{H}_{\mathbf{2}}$ - There is a significant correlation between the communication and level of frustration among the experimental and control group.

\section{*Corresponding author: Pramila Gaudel}

Narayana Hrudayalaya College of Nursing, Bangalore, India 
- $\mathbf{H}_{3}$ - There is a significant association of the communication with their selected baseline variables in the experimental and control group.

- $\quad \mathbf{H}_{\mathbf{4}}$ - There is a significant association of the frustration with their selected baseline variables in the experimental and control group.

\section{MATERIALS AND METHODS}

A quantitative research approach, true experimental design with a post test only control group design was adopted for the present study. Present study was conducted in selected tertiary care hospital at Bangalore. A total sample size of 60 was selected on the basis of inclusion and exclusion criteria, out of which 30 were given communication board when they were in mechanical ventilation post cardio thoracic surgery and 30 underwent regular routine care as per the institution policy. The post test communication and level of frustration was assessed within 72 hours of extubation by using likert scale, in both experimental and control group. Communication board that was prepared as per the need of study, is the display board which consist of pictures to represent the basic needs of mechanically ventilated post cardiothoracic surgery patients, as shown in Figure 1 and Figure 2.

\section{Description of tool}

Tool: Tools used for data collection by the investigator consist of 3 sections namely.

Section A: A structured questionnaire related to demographic variables consist of age, sex, educational status, duration of present illness, associated illness, previous surgery, previous mechanical ventilation, type of surgery and duration of current mechanical ventilation.

Section B: Likert scale that consists of 10 statements including positive and negative statements to assess communication

Section C: Likert scale that consists of 10 statements including positive and negative statements to assess the level of frustration.

\section{Data Analysis}

The data collected was analyzed by means of descriptive statistics and inferential statistics.

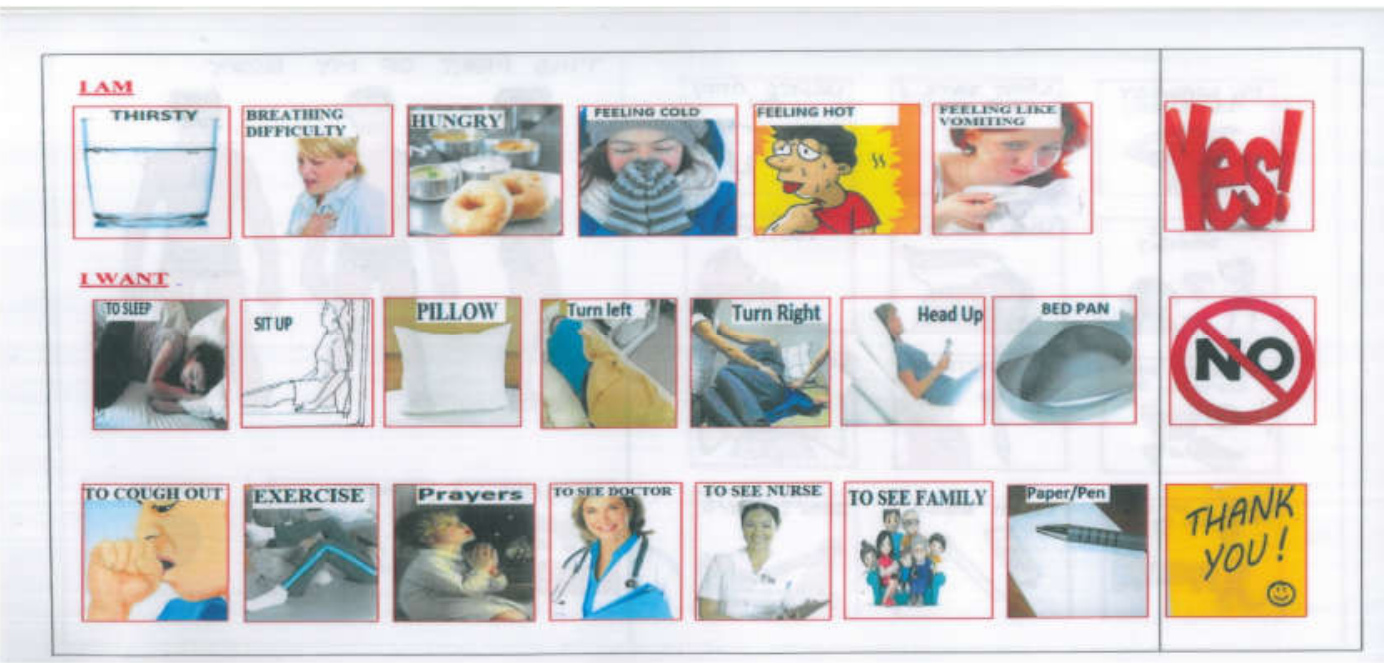

Figure 1 Communication board front view

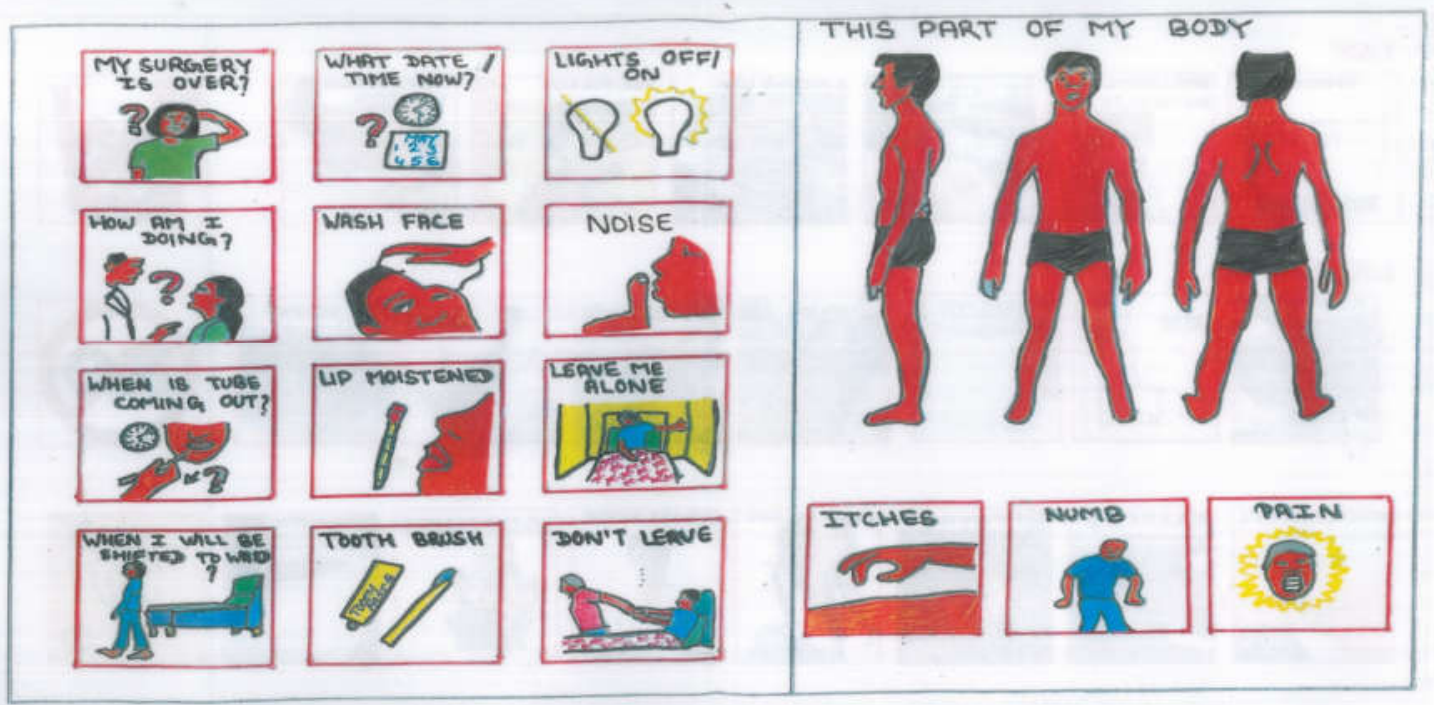

Figure 2 Communication board back view 


\section{Descriptive Statistics}

Frequency, mean and standard deviation are used to assess the demographic data, communication and level of frustration of experimental and control group.

\section{Inferential Statistics}

- Comparison of communication and level of frustration with experimental and control group by using unpaired t-test.

- Correlation of communication and level of frustration among experimental and control group by using correlation coefficient.

- Association of communication and level of frustration in experimental and control group with their selected demographic variables by using chi- square.

\section{Intervention Protocol}

group. Table 3 depicts that level of frustration was severe for none of the patients, moderate for $10 \%$, mild for $76.7 \%$ of the patients and $13.3 \%$ of the patients reported no frustration in the experimental group. In the control group level of frustration was severe for $33.3 \%$ of the patients, moderate for $53.4 \%$, mild for $13.3 \%$ of the patients and none of the patient reported no frustration. Mean frustration score was 25.90 in the experimental group and 35.83 in the control group.

The data in the table 4, shows that the mean value of communication is 34.23 and 22.80 respectively in the experimental and control group with ' $\mathrm{t}$ ' value of 9.051 and it was found to be significant at 0.05 level of significance. The mean value of frustration was 25.90 and 35.83 respectively in the experimental and control group with ' $t$ ' value of -6.604 and it was found to be significant at 0.05 level of significance. Thus the hypothesis $\mathrm{H}_{1}$ was accepted at $<0.05$ level of significance and the null hypothesis was rejected.

Permission obtained from research and ethical committee to conduct study

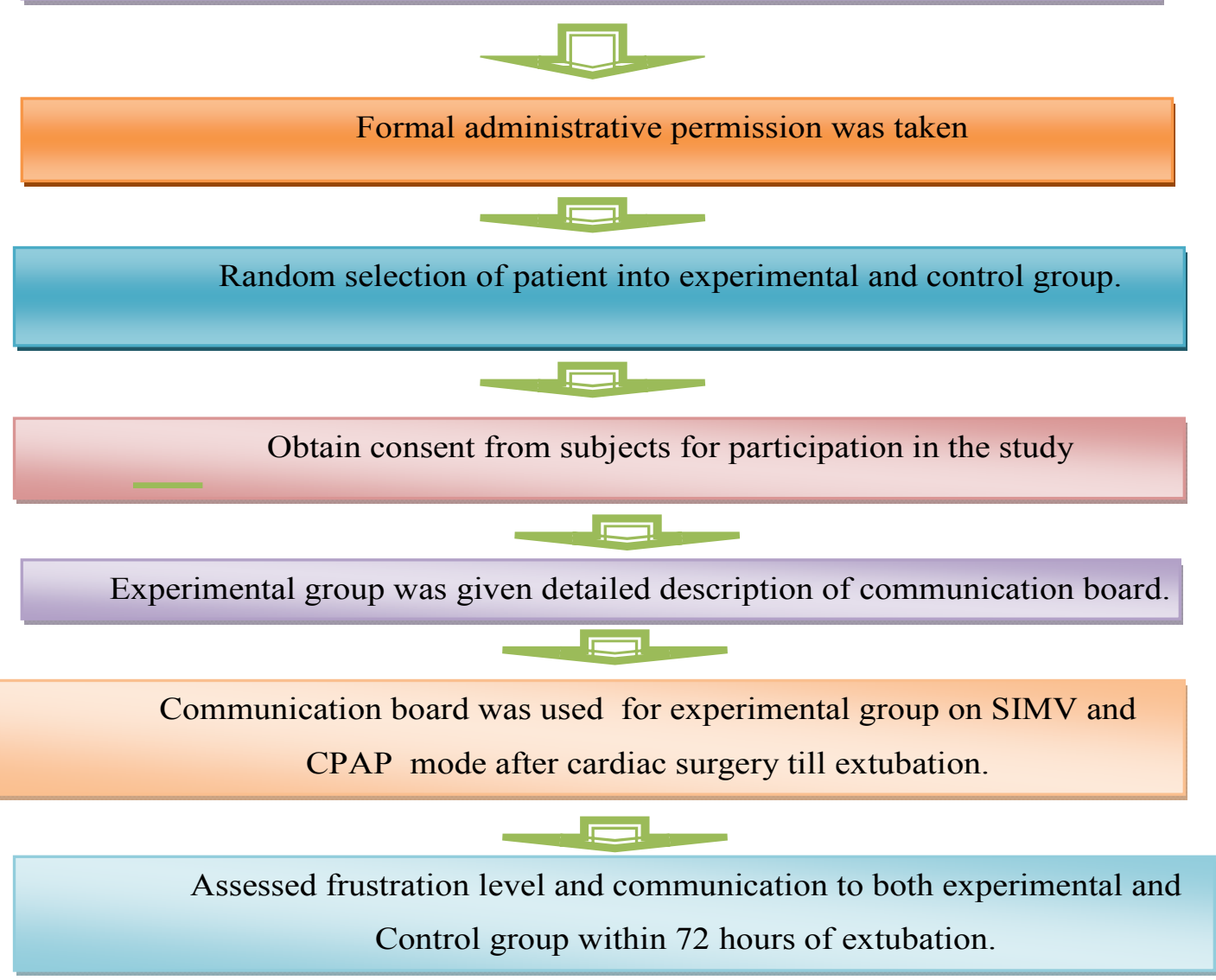

Figure 3 Intervention Protocol

\section{RESULTS}

Table 1 depicts that on comparison of control and experimental group using chi square there was no significant difference hence showing the homogeneity of groups. Table 2 depicits that the communication was very good for $16.6 \%$, good for $56.7 \%$, average for $26.7 \%$ and poor for none of the patients in the experimental group, whereas the communication was very good for none of the patient, good for $10 \%$, average for $63.3 \%$ and poor for $26.7 \%$ of the patients in the control group. Mean communication score was 34.23 in the experimental group and 22.80 in the control
Table 5: shows that there was significant correlation between communication and level of frustration. Pearsons correlation coefficient ( $\mathrm{r}$ ) was -.543 suggesting strong negative correlation between communication and level of frustration. As the calculated value of correlation coefficient between communication and level of frustration was found significant and $\mathrm{H}_{2}$ was accepted. Data presented in the table 6,7 depicts that there was no statistical significant association between the selected variables with communication and level of frustration. Since there was no association of selected 
variables with level of communication and frustration, $\mathrm{H}_{3}$ and

$\mathrm{H}_{4}$ was rejected.

Table 1 Comparison of selected baseline variables between experimental and control group

\begin{tabular}{|c|c|c|c|c|c|c|c|}
\hline \multirow{2}{*}{ S.N } & \multirow{2}{*}{$\begin{array}{c}\text { Demographic } \\
\text { Variables }\end{array}$} & \multicolumn{2}{|c|}{$\begin{array}{l}\text { Control } \\
\text { Group }\end{array}$} & \multicolumn{2}{|c|}{$\begin{array}{c}\text { Experimental } \\
\text { Group }\end{array}$} & \multirow{2}{*}{$\begin{array}{c}\text { Chi square } \\
\text { (P value) }\end{array}$} & \multirow{2}{*}{$\begin{array}{c}\text { Level of } \\
\text { Significance }\end{array}$} \\
\hline & & $\begin{array}{r}\text { Frequency } \\
\mathbf{N}=\mathbf{3 0}\end{array}$ & Percentage (\%) & $\begin{array}{l}\text { Frequency (f) } \\
\quad \mathbf{N}=\mathbf{3 0}\end{array}$ & Percentage (\%) & & \\
\hline \multirow{6}{*}{1.} & Age & & & & & \multirow{6}{*}{$\begin{array}{c}0.356 \\
(0.949)\end{array}$} & \\
\hline & a) $20-30$ & 3 & 10 & 3 & 10 & & \\
\hline & b) $31-40$ & 4 & 13.3 & 5 & 16.6 & & \\
\hline & c) $41-50$ & 6 & 20 & 6 & 20 & & $>0.05$ \\
\hline & d) $51-60$ & 7 & 23.4 & 8 & 26.7 & & NS \\
\hline & e) $>60$ & 10 & 33.3 & 8 & 26.7 & & \\
\hline \multirow{4}{*}{2.} & Gender & & & & & \multirow{3}{*}{$\begin{array}{c}0.067 \\
(0.795)\end{array}$} & \\
\hline & a) Male & 16 & 53.3 & 17 & 56.7 & & $>0.05$ \\
\hline & b) Female & 14 & 46.7 & 13 & 43.3 & & NS \\
\hline & Education & & & & & \multirow{5}{*}{$\begin{array}{c}0.294 \\
(0.961)\end{array}$} & $>0.05$ \\
\hline \multirow{3}{*}{3} & a) Primary education & 5 & 16.6 & 4 & 13.3 & & NS \\
\hline & b) up to 10 th standard & 8 & 26.7 & 9 & 30 & & NS \\
\hline & c) PUC & 6 & 20 & 7 & 23.4 & & \\
\hline \multirow{3}{*}{4.} & d) Graduation and above & 11 & 36.7 & 10 & 33.3 & & \\
\hline & Duration of present illness & & & & & \multirow{6}{*}{$\begin{array}{c}0.420 \\
(0.936)\end{array}$} & \\
\hline & a) $<6$ months & 11 & 36.7 & 9 & 30 & & \\
\hline \multirow{6}{*}{5.} & b) $6-12$ months & 10 & 33.3 & 10 & 33.3 & & \\
\hline & c) 13 months - 2 years & 3 & 10 & 4 & 13.3 & & $>0.05$ \\
\hline & d) $>2$ years & 6 & 20 & 7 & 23.4 & & NS \\
\hline & Associated illness & & & & & & \\
\hline & a) Present & 16 & 53.3 & 17 & 56.7 & \multirow{3}{*}{$\begin{array}{c}0.067 \\
(0.795)\end{array}$} & $>0.05$ \\
\hline & b) Absent & 14 & 46.7 & 13 & 43.3 & & NS \\
\hline \multirow{3}{*}{6.} & Previous surgery & & & & & & \\
\hline & a) Yes & 6 & 20 & 7 & 23.3 & \multirow{3}{*}{$\begin{array}{c}0.098 \\
(0.754)\end{array}$} & $>0.05$ \\
\hline & b) No & 24 & 80 & 23 & 76.7 & & NS \\
\hline \multirow{3}{*}{7.} & \multicolumn{3}{|l|}{ Ventilated previously } & & & & \\
\hline & a) Yes & 3 & 10 & 3 & 10 & \multirow{7}{*}{$\begin{array}{c}0.384 \\
(0.944)\end{array}$} & \\
\hline & b) No & 27 & 90 & 27 & 90 & & \\
\hline \multirow{5}{*}{8.} & Types of surgery & & & & & & \\
\hline & a) Heart Valve surgery & 12 & 40 & 13 & 43.3 & & \\
\hline & b) On Pump CABG & 6 & 20 & 5 & 16.7 & & \\
\hline & c) Off Pump CABG & 9 & 30 & 10 & 33.3 & & $>0.05$ \\
\hline & d) Others & 3 & 10 & 2 & 6.7 & & NS \\
\hline \multirow{4}{*}{9.} & Duration of current ventilation & & & & & \multirow{4}{*}{$\begin{array}{c}0.115 \\
(0.944)\end{array}$} & \\
\hline & a) $<12$ hours & 4 & 13.3 & 4 & 13.3 & & \multirow{3}{*}{$\begin{array}{c}>0.05 \\
\mathrm{NS}\end{array}$} \\
\hline & b) $12-24$ hours & 21 & 70 & 20 & 66.7 & & \\
\hline & c) $25-48$ hours & 5 & 16.7 & 6 & 20 & & \\
\hline
\end{tabular}

Table 2 Overall level of communication in experimental and control group

\begin{tabular}{|c|c|c|c|c|c|c|c|c|c|}
\hline \multirow[t]{2}{*}{ Groups } & \multicolumn{2}{|c|}{$\begin{array}{c}\text { VERY } \\
\text { GOOD } \\
\text { (41-50 score) } \\
\end{array}$} & \multicolumn{2}{|c|}{$\begin{array}{c}\text { GOOD } \\
\text { (31-40 score) }\end{array}$} & \multicolumn{2}{|c|}{$\begin{array}{l}\text { AVERAGE } \\
\text { (21-30 score) }\end{array}$} & \multicolumn{2}{|c|}{$\begin{array}{c}\text { POOR } \\
\text { (10-20 score) }\end{array}$} & \multirow[t]{2}{*}{ Mean Score } \\
\hline & $\mathbf{F}$ & $\%$ & $\mathbf{F}$ & $\%$ & $\mathbf{F}$ & $\%$ & $\mathbf{F}$ & $\%$ & \\
\hline $\begin{array}{c}\text { Experimental } \\
\text { Group }\end{array}$ & 5 & 16.6 & 17 & 56.7 & 8 & 26.7 & - & - & 34.23 \\
\hline $\begin{array}{l}\text { Control } \\
\text { Group }\end{array}$ & - & - & 3 & 10 & 19 & 63.3 & 8 & 26.7 & 22.80 \\
\hline
\end{tabular}

Table 3 Overall level of frustration in experimental and control group

\begin{tabular}{|c|c|c|c|c|c|c|c|c|c|}
\hline & & & & & & & & & $\mathrm{J}=60$ \\
\hline \multirow[t]{2}{*}{ Groups } & \multicolumn{2}{|c|}{$\begin{array}{c}\text { No } \\
\text { Frustration } \\
\text { (10-20 score) } \\
\end{array}$} & \multicolumn{2}{|c|}{$\begin{array}{c}\text { Mild } \\
\text { Frustration } \\
\text { (21-30 score) }\end{array}$} & \multicolumn{2}{|c|}{$\begin{array}{c}\text { Moderate } \\
\text { Frustration } \\
\text { (31-40 score) }\end{array}$} & \multicolumn{2}{|c|}{$\begin{array}{c}\text { Severe } \\
\text { Frustration } \\
\text { (41-50 score) }\end{array}$} & \multirow[t]{2}{*}{$\begin{array}{l}\text { Mean } \\
\text { Score }\end{array}$} \\
\hline & $\mathbf{F}$ & $\%$ & $\mathbf{F}$ & $\%$ & $\mathbf{F}$ & $\%$ & $\mathbf{F}$ & $\%$ & \\
\hline Experimental Group & 4 & 13.3 & 23 & 76.7 & 3 & 10 & - & - & 25.90 \\
\hline Control Group & - & - & 4 & 13.3 & 16 & 53.4 & 10 & 33.3 & 35.83 \\
\hline
\end{tabular}

Table 4 Comparison of mean Communication and Frustration Score between the experimental and control group $\mathrm{N}=60$

\begin{tabular}{cccccc}
\hline & $\begin{array}{c}\text { Experimental } \\
\text { Group }\end{array}$ & $\begin{array}{c}\text { Control } \\
\text { Group }\end{array}$ & Df & $\begin{array}{c}\text { 't' } \\
\text { Value }\end{array}$ & $\begin{array}{c}\text { (independent t- test) } \\
\text { p value }\end{array}$ \\
\cline { 2 - 3 } & Mean \pm SD & Mean \pm SD & & & 0.001 \\
Communication & $34.23 \pm 5.4$ & $22.80 \pm 4.3$ & 58 & 9.051 & 0.001 \\
\hline Frustration & $25.90 \pm 5.2$ & $35.83 \pm 6.3$ & 58 & 6.604 & 0.604 \\
\hline
\end{tabular}


Table 5 Represents correlation of communication and frustration among both experimental and control group

$\mathbf{N}=\mathbf{6 0}$

\begin{tabular}{lc} 
Communication & Frustration \\
& Pearson Correlation -.543 \\
\hline
\end{tabular}

random sampling technique. The data was collected from 60 patients who have undergone cardiothoracic surgery within 72 hours of extubation ( 30 in the experimental group and 30 in the control group) using the likert scale. The result of the study is discussed based on the objectives.

Table 6 Association between communication and selected variables among post cardiothoracic surgery patients

\begin{tabular}{|c|c|c|c|c|c|}
\hline \multirow[b]{3}{*}{$\begin{array}{l}\text { Baseline } \\
\text { Variables }\end{array}$} & \multirow[b]{3}{*}{ Category } & & & \multicolumn{2}{|c|}{$N=60$} \\
\hline & & \multicolumn{2}{|c|}{ Communication } & \multirow[b]{2}{*}{ Chi Square } & \multirow[b]{2}{*}{ P Value } \\
\hline & & $\begin{array}{c}\text { Poor } \\
(\mathbf{N}=31)\end{array}$ & $\operatorname{Good}(N=29)$ & & \\
\hline \multirow{4}{*}{ Age(years) } & $<40$ & $6(19 \%)$ & $9(31 \%)$ & & \\
\hline & $41-50$ & $7(23 \%)$ & $5(17 \%)$ & & 0.610 \\
\hline & $51-60$ & $7(23 \%)$ & $8(28 \%)$ & 1.824 & $>\mathrm{NS}$ \\
\hline & $>60$ & $11(35 \%)$ & $7(24 \%)$ & & \\
\hline \multirow{3}{*}{ Gender } & Male & $15(48 \%)$ & $18(62 \%)$ & \multirow{3}{*}{1.133} & 0.287 \\
\hline & Female & $16(52 \%)$ & $11(38 \%)$ & & $>\mathrm{NS}$ \\
\hline & Primary education & $4(13 \%)$ & $5(17 \%)$ & & \\
\hline \multirow{2}{*}{ Education } & Up to 10 th standard & $10(32 \%)$ & $7(24 \%)$ & \multirow{3}{*}{1.697} & 0.638 \\
\hline & PUC & $5(16 \%)$ & $8(28 \%)$ & & $>\mathrm{NS}$ \\
\hline \multirow{5}{*}{ Duration of present illness } & Graduation and above & $12(39 \%)$ & $9(31 \%)$ & & \\
\hline & $<6$ months & $12(39 \%)$ & $8(27 \%)$ & \multirow{4}{*}{1.154} & \multirow{4}{*}{$\begin{array}{l}0.764 \\
>\mathrm{NS}\end{array}$} \\
\hline & $6-12$ months & $9(29 \%)$ & $11(38 \%)$ & & \\
\hline & 13 months - 2 years & $3(9 \%)$ & $4(14 \%)$ & & \\
\hline & $>2$ years & $7(23 \%)$ & $6(21 \%)$ & & \\
\hline \multirow{2}{*}{ Associated disease } & Present & $18(58 \%)$ & $15(52 \%)$ & \multirow{2}{*}{0.243} & 0.622 \\
\hline & Illness & $3(42 \%)$ & $4(48 \%)$ & & $>\mathrm{NS}$ \\
\hline \multirow{2}{*}{ Previous surgery } & Yes & $6(19 \%)$ & $7(24 \%)$ & \multirow{2}{*}{0.202} & 0.653 \\
\hline & No & $25(81 \%)$ & $22(76 \%)$ & & $>\mathrm{NS}$ \\
\hline \multirow{4}{*}{ Type of surgery } & Heart valve surgery & $12(39 \%)$ & $13(45 \%)$ & \multirow{4}{*}{0.317} & \\
\hline & On pump $\mathrm{CABG}$ & $6(19 \%)$ & $5(17 \%)$ & & 0.957 \\
\hline & Off pump CABG & $10(32 \%)$ & $9(31 \%)$ & & $>\mathrm{NS}$ \\
\hline & Others & $3(10 \%)$ & $2(7 \%)$ & & \\
\hline \multirow{3}{*}{$\begin{array}{l}\text { Duration of current } \\
\text { ventilation }\end{array}$} & $<12$ hours & $4(13 \%)$ & $4(14 \%)$ & \multirow{3}{*}{0.244} & \multirow{3}{*}{$\begin{array}{l}0.885 \\
>\mathrm{NS}\end{array}$} \\
\hline & $12-24$ hours & $22(71 \%)$ & $19(65 \%)$ & & \\
\hline & $25-48$ hours & $5(16 \%)$ & $6(21 \%)$ & & \\
\hline
\end{tabular}

Table 7 Association between level of frustration and selected variables among post cardiothoracic surgery group.

\begin{tabular}{|c|c|c|c|c|c|}
\hline \multirow{2}{*}{$\begin{array}{c}\text { Baseline } \\
\text { Variables }\end{array}$} & \multirow{2}{*}{ Category } & \multicolumn{2}{|c|}{ Frustration } & \multirow{2}{*}{ Chi square } & \multirow{2}{*}{$P$ value } \\
\hline & & Low & High & & \\
\hline \multirow{4}{*}{ Age(years) } & $<40$ & $10(29 \%)$ & $5(19 \%)$ & \multirow{4}{*}{1.584} & \\
\hline & $41-50$ & $6(18 \%)$ & $6(23 \%)$ & & 0.663 \\
\hline & $51-60$ & $7(21 \%)$ & $8(31 \%)$ & & $>\mathrm{NS}$ \\
\hline & $>60$ & $11(32 \%)$ & $7(27 \%)$ & & \\
\hline \multirow{2}{*}{ Gender } & Male & $19(56 \%)$ & $14(54 \%)$ & \multirow{2}{*}{0.025} & 0.875 \\
\hline & Female & $15(44 \%)$ & $12(46 \%)$ & & $>\mathrm{NS}$ \\
\hline \multirow{4}{*}{ Education } & Primary education & $6(18 \%)$ & $3(12 \%)$ & \multirow{4}{*}{0.507} & 0.917 \\
\hline & Up to 10 th standard & $9(26 \%)$ & $8(31 \%)$ & & $>\mathrm{NS}$ \\
\hline & PUC & $7(21 \%)$ & $6(23 \%)$ & & \\
\hline & Graduation and above & $12(35 \%)$ & $9(34 \%)$ & & \\
\hline \multirow{4}{*}{ Duration of present illness } & $<6$ months & $12(35 \%)$ & $8(31 \%)$ & \multirow{4}{*}{0.767} & \\
\hline & $6-12$ months & $12(35 \%)$ & $8(31 \%)$ & & 0.857 \\
\hline & 13 months - 2 years & $3(9 \%)$ & $4(15 \%)$ & & $>\mathrm{NS}$ \\
\hline & $>2$ years & $7(21 \%)$ & $6(23 \%)$ & & \\
\hline \multirow{2}{*}{$\begin{array}{l}\text { Associated } \\
\text { diseases }\end{array}$} & Present & $19(56 \%)$ & $14(54 \%)$ & \multirow{3}{*}{0.025} & 0.875 \\
\hline & Absent & $15(44 \%)$ & $12(46 \%)$ & & $>\mathrm{NS}$ \\
\hline \multirow{2}{*}{ Previous surgery } & Yes & $7(21 \%)$ & $6(23 \%)$ & & 0.817 \\
\hline & No & $27(79 \%)$ & $20(77 \%)$ & \multirow[t]{2}{*}{0.054} & $>\mathrm{NS}$ \\
\hline \multirow{3}{*}{ Type of surgery* } & Heart valve surgery & $16(47 \%)$ & $9(34 \%)$ & & \\
\hline & On pump $\mathrm{CABG}$ & $4(12 \%)$ & $7(27 \%)$ & \multirow{3}{*}{-} & \\
\hline & Off pump CABG & $11(32 \%)$ & $8(31 \%)$ & & - \\
\hline \multirow{4}{*}{$\begin{array}{c}\text { Duration of } * \text { current } \\
\text { ventilation }\end{array}$} & Others & $3(9 \%)$ & $2(8 \%)$ & & \\
\hline & $<12$ hours & $4(12 \%)$ & $4(15 \%)$ & \multirow{3}{*}{-} & \multirow{3}{*}{ - } \\
\hline & 12-24 hours & $23(67 \%)$ & $18(70 \%)$ & & \\
\hline & $25-48$ hours & $7(21 \%)$ & $4(15 \%)$ & & \\
\hline
\end{tabular}

* Some cells have expected count less than 5 so could not find chi-square value

\section{DISCUSSION}

Mechanically ventilated post cardiothoracic surgery patients who fit the inclusion criteria were selected using clustered
The first objective was to assess level of communication and frustration among experimental and control group using Likert scale 
It is noted that the communication was very good for $16.6 \%$, good for $56.6 \%$, average for $26.6 \%$ and poor for none of the patients in the experimental group, whereas the communication was very good for none of the patient, good for $10 \%$, average for $63.3 \%$ and poor for $26.6 \%$ of the patients in the control group.

It is noted that level of frustration was severe for none of the patients, moderate for $10 \%$, mild for $76.6 \%$ of the patients and $13.3 \%$ of the patients reported no frustration in the experimental group. In the control group level of frustration was severe for $33.3 \%$ of the patients, moderate for $53.3 \%$, mild for $13.3 \%$ of the patients and none of the patient reported no frustration.

This indicates that mechanically ventilated post cardiothoracic surgery patients in the experimental group had communication ranging from average to very good whereas in the control group had communication ranging from poor to good.

The finding shows that mechanically ventilated post cardiothoracic surgery patients in the experimental group had level of frustration ranging from no frustration to moderate frustration whereas in the control group level of frustration was ranging from mild frustration to severe frustration.

A study was conducted to assess the patient satisfaction in hospital among post operative patients. Many patients complained that they were not treated with respect by the caregivers, did not receive adequate pain medication after surgery. The author claimed that poor communication was a major source of medical errors, encouraging doctors and nurses to listen more carefully to their patients. An independent $t$ test indicated that a planned method of communication does significantly increase patient satisfaction in the early postoperative intubation period $(\mathrm{t}=2.09, \mathrm{p}=0.05$, $\mathrm{n}=35)[10]$.

An Explorative study was done to identify the patients' experiences and preferences for augmentative and alternative methods during mechanical ventilation, for which 18 patients were interviewed in an acute care medical ICU. Most of the patients $(69 \%)$ perceived that a communication board would have been helpful and also identify specific characteristics and content for a communication board. A communication board may be effective intervention for decreasing patient's frustration and facilitating communication [3].

The second objective was to assess the effectiveness of communication board on communication and level of frustration among mechanically ventilated post cardiothoracic surgery patients.

The effectiveness of communication board on communication and level of frustration among mechanically ventilated post cardiothoracic surgery patients was discussed as follows:

The mean value of communication score was 34.23 with standard deviation of 5.4 and $t$ value of 9.051 and was found to be significant at $<0.05$ level among interventional groups. The mean value of communication score was 22.8 with standard deviation of 4.3 and $t$ value of 9.051 and was found to be significant at $<0.05$ level among control groups.

The mean value of frustration score was 25.90 with standard deviation of 5.2 and $t$ value of -6.604 and was found to be significant at $<0.05$ level among interventional groups. The mean value of frustration score was 35.83 with standard deviation of 6.3 and $t$ value of -6.604 and was found to be significant at $<0.05$ level among control groups.

Similar study was done among nurses and patients regarding methods used to communicate. Pre-intervention assessments reported $60 \%$ of mechanically ventilated patients were extremely frustrated with their inability to communicate and $75 \%$ of nurses perceived their methods and resources to be inadequate. Post intervention assessment reported 51\% of patients preferred the EZ Board as their best method compared to other communication aids and basic methods, and $58 \%$ of nurses reported the EZ Board as the most beneficial method [8].

A similar true experimental design study was conducted involving 400 intubated patients with 200 subjects being allocated equally in both experimental and control group. The study was conducted in the post operative intensive care unit of a cardiac hospital in Chennai. The major findings of the study revealed that in the experimental group, 192(96\%) of the subjects were able to meet their needs adequately after using the communication board as compared to $7(3.5 \%)$ in control group. The level of satisfaction was increased in post test for subjects of experimental group after using the communication board as compared to the control group who were subjected to hospital routine mode of communication method [11].

The third objective was to find correlation between communication and level of frustration among the experimental and control group

The study result showed that there is a statistical significant correlation between the communication and level of frustration. Pearsons corelation coefficient ( $\mathrm{r}$ ) was -.543 suggesting strong negative correlation between communication and level of frustration. Therefore research hypothesis $\mathbf{H}_{2}$ was accepted at $\mathrm{p}<0.05$.

A similar study was conducted to assess the effectiveness of communication board on communication pattern and level of satisfaction among mechanically ventilated patients in selected hospitals, Bangalore. The correlation coefficient (r) was +0.097 which was found to be positive at 0.05 level. As the calculated value of correlation coefficient between communication pattern and level of satisfaction in experimental group was found non-significant and the $\mathbf{H}_{\mathbf{2}}$ was not accepted. [6]

The fourth objective was to find association between communication and level of frustration of experimental group and control group with their selected baseline variables.

The baseline variables studied are the age, gender, education, duration of present illness, associated illness, previous surgery, ventilated previously, type of surgery and duration of current ventilation. The findings of the study showed that in both control group and interventional group there was no significant association between communication with their selected baseline variables like age $\left(x^{2}=1.824\right)$, gender $\left(x^{2}\right.$ $1.133)$, education $\left(x^{2}=1.697\right)$, duration of present illness $\left(\mathrm{x}^{2}=1.154\right)$, associated illness $\left(\mathrm{x}^{2}=0.243\right)$, previous surgery $\left(x^{2}=0.202\right)$, types of surgery $\left(x^{2}=0.317\right)$, duration of current ventilation $\left(\mathrm{x}^{2}=0.244\right)$ at $5 \%$ level. Similarly there was no association of level of frustration with their selected baseline variables like age $\left(x^{2}=1.584\right)$, gender $\left(x^{2} 0.025\right)$, education 
$\left(\mathrm{x}^{2}=0.507\right)$, duration of present illness $\left(\mathrm{x}^{2}=0.767\right)$, associated illness $\left(x^{2}=0.025\right)$, previous surgery $\left(x^{2}=0.054\right)$ at $5 \%$ level.

Hence, $\mathrm{H}_{3}$ and $\mathrm{H}_{4}$ were rejected as there was no significant association of communication and level of frustration with their selected baseline variables in both the experimental and control group.

A similar study to assess the effectiveness of communication board on communication pattern and level of satisfaction among mechanically ventilated patients in selected hospitals, Bangalore shows that there was no significant association of communication pattern of experimental group and control group with selected demographic variables. [6]

\section{CONCLUSION}

Findings of the study revealed that the communication board was effective in improving communication $(\mathrm{t}=9.051, \mathrm{p}=$ $0.001)$ and frustration $(t=-6.604, p=0.001)$ of mechanically ventilated post cardio thoracic surgery patients. There was a statistical significant strong negative correlation $(r=-.543)$ between the communication and level of frustration. And there was no significant association between communication and level of frustration $(\mathrm{p}=0.05)$ with their selected baseline variables in both the experimental and control group.

\section{Acknowledgement}

We would like to show our gratitude to all the patients who participated in this study.

\section{References}

1. Bhaskar N, Elakkuvana BR. Text book of nursing education. India: Emmess medical; 2003. p. 551-54.

2. Fried OM, Howard J, Stewart S. Feedback on AAC intervention from adults who are temporarily unable to speak augmentative and alternative Communication.1991; 7:43-50.

3. Happ MB. Communicating with mechanically ventilated patients: state of the science. AACN clinical issues: Advanced Practice in Acute and Critical Care. 2001 May: 12(2): p 247- 58.

4. Kaul U, Bhatia V. Perspective on coronary interventions \& cardiac surgeries in India. Indian $J$ Med Res. Nov 2010; 132(5):543-548.

5. Lewis SL, Heitkemper MM, Dirksen SR, Bucher L. Lewis's medical surgical nursing. South Asian Edition. Haryana, India: Elsevier; 2011. p.1758-59.

6. Lourdu SR. Effectiveness of communication board among mechanically ventilated patients. 2015 April; $9(1): 145-7$

7. Promoting cardiovascular health in the developing world: A critical challenge to achieve global health. Available from: http://www.ncbi.nlm.nih.gov/books/ NBK45688/.

8. Reed C. The role of education and innovative communication tools in improving non-verbal communication. University of Texas Health Sciences Center. 2008; 19(4):182-90.

9. Smeltzer SC, Bare BG, Hinkle JL, Cheever KH. Brunner and Suddarth's textbook of medical surgical nursing. 11th ed. New Delhi: Wolters kluwer; 2009. p. 739-43.

10. Stovsky B, Rudy E, Dragonette P. Comparison Of Two Types Of Communication Methods Using After Cardiac Surgery With Patient With Endo tracheal intubation; Heart Lung. 1988 May; 17(3): 281-9.

11. http://www.ncbi.nlm.nih.gov/pubmed/22045144. (Last accessed Sept 22 2016)

Please cite this article in press as:

Pramila Gaudel and Jamuna Bai (2017), 'Effectiveness Of Communication Board On Communication And Level Of

Frustration Among Mechanically Ventilated Post Cardiothoracic Surgery Patients', International Journal of Current Advanced Research, 6(3), pp. 2980-2986.http://dx.doi.org/10.24327/ijcar.2017. 2986.0160 